\title{
Diversity, distribution and floral specificity of tangle-veined flies (Diptera: Nemestrinidae) in north west Patagonia, Argentina
}

\author{
Diversidad, distribución y especificidad floral de nemestrínidos (Diptera) \\ en el noroeste de la Patagonia, Argentina
}

MARIANO DEVOTO \& DIEGO MEDAN

\begin{abstract}
Cátedra de Botánica, Facultad de Agronomía de la Universidad de Buenos Aires, Avenida San Martín 4453 (C1417DSE), Buenos Aires, Argentina;

e-mail for correspondence: mdevoto@agro.uba.ar
\end{abstract}

\begin{abstract}
Tangle-veined flies (Nemestrinidae) constitute a primitive and rather widespread family among Diptera. The genus Trichophthalma occurs in Australia and South America and is the only one in the family with a typically Gondwanian, disjoint distribution. The ecology and distribution of most southern South American species of this genus remains virtually unknown. We studied the diversity, distribution and flower specificity of flower-visiting species of the genus Trichophthalma in the temperate forests of southern South America in ten sites along an east-west rainfall gradient $\left(37-40^{\circ} \mathrm{S}\right)$ on the eastern slope of the Andes. We recorded nine species of Trichophthalma, which showed an overlapped distribution along the gradient and different degrees of floral specificity. Three species are reported for Argentina for the first time and three are first recorded as flower visitors to the local flora. Our results show that while in southern Africa tangle-veined flies are engaged in highly specialized pollination interactions with long-tubed species, the Trichophthalma spp. of Patagonia share their flowers with a diverse and rather unspecialized visitor fauna among which several species of flies, bees and birds are present.
\end{abstract}

Key words: Diptera, Nemestrinidae, Trichophthalma, pollination Patagonia.

\section{RESUMEN}

Los nemestrínidos constituyen una familia de Dípteros primitiva y de amplia distribución. El género Trichophthalma se encuentra en Australia y Sudamérica y es el único en la familia con una distribución disjunta típicamente gondwánica. La ecología y distribución de la mayoría de las especies sudamericanas permanecen virtualmente desconocidas. Estudiamos la diversidad, distribución y especificidad floral de las especies del género Trichophthalma de los bosques templados del sur de Sudamérica en diez sitios ubicados a lo largo de un gradiente de precipitación este-oeste $\left(37-40^{\circ} \mathrm{S}\right)$ sobre la vertiente occidental de los Andes. Registramos nueve especies de Trichophthalma, las cuales mostraron una distribución superpuesta a lo largo del gradiente y diferentes grados de especificidad floral. Tres de las especies fueron registradas por primera vez para Argentina, y tres fueron registradas por primera vez visitando especies de la flora local. Nuestros resultados muestran que mientras en el sur de África los nemestrínidos se involucran en interacciones de polinización altamente especializadas con especies de tubo floral largo, las especies de Trichophthalma de Patagonia comparten sus flores con una fauna diversa y poco especializada en la cual están presentes varias especies de moscas, abejas y aves.

Palabras clave: Diptera, Nemestrinidae, Trichophthalma, polinización, Patagonia.

\section{INTRODUCTION}

Nemestrinidae are picturesque flies (Diptera, Brachycera, Asiloidea) that have the ability to hover, keeping up a high-pitched hum (Cole 1969). They are widespread throughout the globe, but there are some areas of higher concentration: from the Mediterranean to Turkistan, eastern Australia, southern Africa, Chile and Argentina (Bernardi 1973). Thirty years ago there were about 150 described species (Cole 1969), but since then several new species have been added (e.g., Bernardi 1975, 1977) and many might remain undescribed 
(Goldblatt \& Manning 2000, N. Woodley personal communication).

The family is rather primitive among Diptera and was probably one of the first ones to feed on the nectar of early angiosperms during the early Cretaceous (Willemstein 1987, Mostovski \& Martinez Delclos 2000). Fossil records show that Nemestrinidae were already present in the Jurassic in the Palearctic region (Bernardi 1973; Mostovski \& Martinez Delclos 2000).

Two extant subfamilies, the Nemestrininae and the Hirmoneurinae, are the most primitive and the most widely distributed. Nemestrininae genera are geographically segregated in South America and Australia (genus Trichophthalma), southern Africa (Prosoeca and Stenobasipteron) and the Palearctic region (Nemestrinus and Stenopteromyia, with a branch that, later, reached Africa, giving rise to Moegistorhynchus) (Bernardi 1973). In South America, several species of Nemestrinidae belonging to the sub-families Hirmoneurinae (represented by the genus Hirmoneura) and Trichopsideinae (Neorhynchocephalus spp.) have also been described.

Trichophthalma occurs in Australia and South America and is the only case in the family (though not in nature, see Raven \& Axelrod 1974, 1975 and references therein) of a genus with such a disjunct (typically Gondwanian) distribution. This genus has 45 Australian species and 21 species described for southern South America (Argentina, Chile and Uruguay) (Bernardi 1973, 1975).

In spite of its primitiveness, Trichophthalma shows a rather specialized character (shared by all Nemestrininae): the proboscis is always well developed and it can range between 1.4 to 7 times the height of the head (as measured by Angulo 1971), being sometimes longer than the whole insect, as in T. scalaris of Chile (Angulo 1971). Species with long proboscides are able to reach nectar hidden in deep flower tubes, which has lead to remarkably specialized mutualisms (Goldblatt \& Manning 2000, Johnson \& Steiner 2000, and references therein).

In spite of their widespread distribution and nectar-feeding habit, pollination by tangleveined flies is a most unusual phenomenon that has only been reported for southern Africa and South America (for the first time by Marloth
1908 and Edwards 1930, respectively). However, unlike southern African species, which have received much attention (Goldblatt \& Manning 2000, and references therein), the ecology and distribution of most southern South American species remains virtually unknown (Peña 1996).

Trichophthalma is a diverse genus within the temperate forests of southern South America (Stuardo 1939, Angulo 1971, Bernardi 1973). These forests extend over a narrow strip from ca. 35 to $55^{\circ} \mathrm{S}$ latitude over much of southern Chile and the eastern slope of the Patagonian Andes in Argentina (Donoso Zegers 1993, Arroyo et al. 1996). In this region, there is a strong rainfall gradient (Paruelo et al. 1998a) which encompasses a striking shift in vegetation in less than $150 \mathrm{~km}$ in an east-west direction from xeric desert shrubland to grassshrub steppe, leading to a low stature tree cover and finally closed canopy forest (Movia et al. 1982, Paruelo et al. 1998b, Austin \& Sala 2002).

As part of a community-level survey in NW Patagonia (Argentina) (Devoto et al. 2005), we focused on the diversity and distribution of flower-visiting Nemestrinidae and their floral specificity along the rainfall gradient mentioned above.

\section{MATERIAL AND METHODS}

The study was carried out on the eastern slope of the Patagonian Andes within the Nahuel Huapi and Lanín national parks in Argentina, approximately between $39-40^{\circ} \mathrm{S}$ and $71-72^{\circ} \mathrm{W}$. The study sites encompassed from humid Nothofagus-dominated forests (close to the Valdivian rainforests of Chile) to the easternmost outskirts of Austrocedrusdominated dry forests on the border of the grass-shrub Patagonian steppe (Paruelo et al. 1998b). From the Andes and eastward through the region, the amount of annual rainfall decreases exponentially reaching less than 200 $\mathrm{mm}$ per year in most of the central portion of Patagonia (Paruelo et al. 1998a, Soriano 1983). A characteristic of the temperature pattern throughout the region is the NW-SE distribution of the isotherms, determined mainly by the presence of the Andes (Paruelo et al. 1998a). Mean annual temperatures in the 
study region range from ca. $10{ }^{\circ} \mathrm{C}$ on the eastern side to ca. $8{ }^{\circ} \mathrm{C}$ on the western side (Movia et al. 1982).

Within the described region, we selected ten sites encompassing an annual rainfall from 700 to $2,550 \mathrm{~mm}$ (a ca. 3.6-fold change) and a 0.4fold change in altitude (Table 1, Movia et al. 1982). General patterns of variation at the community level have been described elsewhere (Devoto et al. 2005). In the present work, we focused on the diversity, distribution and floral specificity of Nemestrinidae.

At each site, 3-5 well-trained observers recorded flower-visitors to the local flora over a period of 7-8 days in mid-December. Additionally, a reduced team of one to two observers re-visited most sites in mid-January and/or mid-December of a later year (see Table 1 for details). We sampled on several plants at different times of the day and on different days. Every flower-visiting tangle-veined flies observed were captured, the only exception being $T$. niveibarbis at two sites (see Table 2 for details) which was extremely abundant and only a few individuals were caught. We pinned insects for later identification at the laboratory. We made determinations using available keys and descriptions (Stuardo 1939, Angulo 1971, Bernardi 1973) and comparing with reference collections at the Museo Argentino de Ciencias Naturales "Bernardino Rivadavia" (Buenos Aires) and Museo de La Plata (La Plata) whenever possible. At Caviahue, fieldwork was non-systematic and performed by one observer on a single trip of two days in December. The results from this site are shown, but not included in statistical analyses. All the material is deposited at our department. For our analysis, we included information from comparable studies in the same area from Argentina and Chile (Edwards 1930, Stuardo 1939, Angulo 1971, Bernardi 1973, Riveros et al. 1991, Aizen et al. 2002, Vázquez \& Simberloff 2002, 2003, 2004, Smith-Ramírez et al. 2005).

\section{Quality of the data set}

Species turnover in pollinator communities can be very significant over time and space (e.g., Williams et al. 2001, Potts et al. 2003, Herrera 2005). Spatial variability was accounted for by sampling in several sites encompassing much of the environmental variation of the region. The complete absence of species of Trichophthalma in the two driest sites (in spite of the considerable sampling effort employed there, see Results) suggests that samplings included the total longitudinal distribution of Nemestrinidae, at least on the eastern hang of the Andes. Regarding seasonal variation, we believe that the relatively short sampling window we used did not seriously flaw our data given the unimodal and strongly seasonal reproductive phenology of the communities studied, where the activity of most plants and pollinators is markedly concentrated in December and, to a lesser extent, in January (Smith-Ramírez \& Armesto 1994, Riveros \& Smith-Ramírez 1996). A similar phenological pattern has been described also for the steppe habitats on the driest sites of the gradient (Soriano et al. 1976). A third concern is that our survey may undersample inter-annual variation. We hope to have partially circumvented this problem by sampling six out of ten sites in at least two different seasons (Table 1). Unfortunately, four sites were sampled for only one season (though two of them were visited twice within the same season) due to logistical reasons (our laboratory and the study region are $1,500 \mathrm{~km}$ apart).

Finally, we evaluated whether the uneven sampling effort among sites (Table 1) had affected the number of species recorded at each site (Table 2). However, the correlation between total sampling effort and the number of species of Trichophthalma recorded at each site was not significant $\left(\mathrm{P}=0.998, \mathrm{R}^{2}=\right.$ 0.000001 , curve not shown).

\section{RESULTS}

Diversity and distribution of Nemestrinidae in NW Patagonia

In eight out of ten communities surveyed (see Table 1 for details), we recorded tangle-veined flies visiting flowers of the local flora (Table 2, see Table 3 for a description of plants visited). Overall, we recorded nine different species of Trichophthalma (including two undescribed taxa: specie nova 1 and 2, Table 2), which showed an overlapped distribution along the gradient (Table 2). Three of the species were 
previously unrecorded for Argentina ( $T$. andina, $T$. porteri and $T$. niveibarbis, comparing with the only lists of species published by Stuardo 1939 and Bernardi 1973). After standardization for sampling effort, the variation in species number throughout the gradient adjusted to a second-degree polynomial function with a maximum at ca. $1.700 \mathrm{~mm}$ (Fig. 1). Eastward and westward from this point, diversity of tangled-veined flies decreased towards both ends of the gradient. In the two driest sites, LL and CT, we found no species of Nemestrinidae foraging on flowers.

\section{Floral specificity}

Tangle-veined flies showed different degrees of floral-specificity and visited on average 1.88 plant species $($ range $=1-4$, Tables 3 and 4). Considering the previous records for Nahuel Huapi $(\mathrm{NH})$ region (T. amoena visiting Berberis buxifolia, B. darwinii, Ribes magellanicum and Schinus patagonicus, and T. jaffueli visiting Alstroemeria aurea and Rosa eglanteria; Vázquez \& Simberloff 2003, 2004) the mean rises to 2.3 (range 1-6). The most generalist species was $T$. amoena, which visited six different plant species throughout its range (considering data from Table 3 and from Vázquez \& Simberloff 2003, 2004). Some species had wide distribution ranges and visited several plant species throughout the gradient ( $T$. jaffueli, Table 3), whereas others had more narrow ranges and visited a single plant species across their distribution (e.g., T. niveibarbis, Table 3). A few additional records were not included in our analysis as they were too far from our study area ( $T$. philippii on Chaetanthera microphylla and Stachys albicaulis in the subandean scrub of central Chile, Arroyo et al. 1982; T. porteri on Trevoa quinquenervia at Fundo Santa Lara, Quillota, Chile, D. Medan unpublished results; T. herbstii and T. commutata on Eucryphia cordifolia at Chiloé, Chile, Smith-Ramírez et al. 2005; T. jaffueli on Senecio patagonicus at Lago Argentino, Santa Cruz province, Argentina, D. Medan unpublished results). There was no significant relationship between the length of the proboscides of the captured species of Trichophthalma and the number of plant species they were recorded visiting $\left(\mathrm{P}=0.276, \mathrm{~F}_{1,7}=\right.$ 1.39; $\mathrm{R}^{2}=0.16$; from data on Table 3 ).

TABLE 1

Dates of field observations, geographic coordinates, mean annual rainfall and altitude of ten study sites in NW Patagonia, Argentina. Sampling effort was calculated as fieldwork days x number of persons participating in fieldwork $\mathrm{x}$ number of hours of observations per day

Fechas de observaciones de campo, coordenadas geográficas, precipitación media anual y altitud de diez sitios de estudio en el NO de Patagonia, Argentina. El esfuerzo de muestreo se calculó como número de días de trabajo de campo x número de personas participantes en el trabajo de campo x número de horas de observaciones por día

\begin{tabular}{|c|c|c|c|c|c|c|c|c|c|c|}
\hline $\begin{array}{l}\text { Site } \\
\text { (abbreviation) }\end{array}$ & $\begin{array}{l}\text { Lago } \\
\text { Queñi } \\
\text { (LQ) }\end{array}$ & $\begin{array}{c}\text { Paso } \\
\text { Puyehue } \\
\text { (PP) }\end{array}$ & $\begin{array}{c}\text { Lago } \\
\text { Tromen } \\
\text { (LT) }\end{array}$ & $\begin{array}{c}\text { Arroyo } \\
\text { Pedregoso } \\
\text { (AP) }\end{array}$ & $\begin{array}{c}\text { Vda. de } \\
\text { Barriga } \\
\text { (VB) }\end{array}$ & $\begin{array}{l}\text { Villa } \\
\text { Traful } \\
(\text { VT) }\end{array}$ & $\begin{array}{l}\text { Lago Hue- } \\
\text { chulafquen } \\
\text { (LH) }\end{array}$ & $\begin{array}{c}\text { Caviahue } \\
\text { CA) }\end{array}$ & $\begin{array}{c}\mathrm{La} \\
\text { Lipela } \\
(\mathrm{LL})\end{array}$ & $\begin{array}{c}\text { Confluencia } \\
\text { Traful } \\
\text { (CT) }\end{array}$ \\
\hline Date of field observations & $\begin{array}{c}\text { Dec } 1999 \\
\text { Jan } 2000\end{array}$ & Dec 2001 & $\begin{array}{l}\text { Dec } 1998 \\
\text { Dec } 2003\end{array}$ & $\begin{array}{c}\text { Dec } 2001 \\
\text { Dec } 2002 \\
\text { Jan } 2003\end{array}$ & $\begin{array}{l}\text { Dec } 1997 \\
\text { Dec } 2003\end{array}$ & $\begin{array}{c}\text { Dec } 2001 \\
\text { Dec } 2002 \\
\text { Jan } 2003\end{array}$ & $\begin{array}{l}\text { Dec } 1997 \\
\text { Dec } 2003\end{array}$ & Jan 2002 & $\begin{array}{c}\text { Dec } 2000 \\
\text { Jan } 2001\end{array}$ & $\begin{array}{c}\text { Dec } 2001 \\
\text { Dec } 2002 \\
\text { Jan } 2003\end{array}$ \\
\hline Geographic coordinates & $\begin{array}{l}40^{\circ} 09^{\prime} \mathrm{S}, \\
71^{\circ} 43^{\prime} \mathrm{W}\end{array}$ & $\begin{array}{l}40^{\circ} 44^{\prime} \mathrm{S}, \\
71^{\circ} 53^{\prime} \mathrm{W}\end{array}$ & $\begin{array}{l}39^{\circ} 34^{\prime} \mathrm{S}, \\
71^{\circ} 26^{\prime} \mathrm{W}\end{array}$ & $\begin{array}{l}40^{\circ} 37^{\prime}, \mathrm{S}, \\
71^{\circ} 35^{\prime} \mathrm{W}\end{array}$ & $\begin{array}{c}39^{\circ} 45^{\prime} \mathrm{S} \\
71^{\circ} 22^{\prime} \mathrm{W}\end{array}$ & $\begin{array}{l}40^{\circ} 39^{\prime} \mathrm{S}, \\
71^{\circ} 21^{\prime} \mathrm{W}\end{array}$ & $\begin{array}{l}39^{\circ} 48^{\prime} \mathrm{S} \\
71^{\circ} 12^{\prime} \mathrm{W}\end{array}$ & $\begin{array}{l}37^{\circ} 51^{\prime} \mathrm{S}, \\
71^{\circ} 01^{\prime} \mathrm{W}\end{array}$ & $\begin{array}{l}40^{\circ} 48^{\prime} \mathrm{S}, \\
71^{\circ} 06^{\prime} \mathrm{W}\end{array}$ & $\begin{array}{l}40^{\circ} 43^{\prime} \mathrm{S}, \\
71^{\circ} 05^{\prime} \mathrm{W}\end{array}$ \\
\hline Mean annual rainfall (mm) & 2,550 & 2,000 & 1,750 & 1,700 & 1,450 & 1,250 & 1,050 & 1,000 & 750 & 700 \\
\hline Altitude (m) & 800 & 950 & 1,000 & 870 & 970 & 900 & 780 & 1,653 & 735 & 727 \\
\hline Sampling effort (h) & 304 & 48 & 180 & 68 & 32 & 92 & 232 & 4 & 320 & 92 \\
\hline
\end{tabular}


TABLE 2

Distribution of Trichophthalma species along a rainfall gradient in NW Patagonia, Argentina. Presence-absence data are based on our own field records and previous studies ( $\dagger$ Bernardi 1973, $\ddagger$ Vázquez \& Simberloff 2003, 2004). Although for some species field records were discontinuous along the gradient, we assumed their presence in intermediate sites $(\S)$. For our own records, numbers indicate the quantity of individuals caught at each site. Captures of T. niveibarbis at LT and VB were kept to a minimum. $\mathrm{CH}=$ records from several sites on the Chilean slopes of the Andes at ca. the same latitude (Stuardo 1939, Angulo 1971, Bernardi 1973), PB = Puerto Blest, LQ $=$ Lago Queñi, PP = Paso Puyehue, $\mathrm{LT}=$ Lago Tromen, $\mathrm{AP}=$ Arroyo Pedregoso, VB $=$ Viuda de Barriga, VT = Villa Traful, $\mathrm{LH}=$ Lago Huechulafquen, $\mathrm{C}=$ Caviahue, $\mathrm{LL}=$ La Lipela, $\mathrm{CT}=$ Confluencia Traful. Annual rainfall values $(\mathrm{mm})$ are given for each site. For simplicity, records from previous studies were assigned, when possible, to one of our own sites with equivalent annual rainfall

Distribución de especies de Trichophthalma a lo largo de un gradiente de precipitación en el NO de Patagonia, Argentina. Los datos de presencia-ausencia se basan en nuestros propios registros de campo y en estudios previos $(\dagger$ Bernardi $1973, \$$ Vázquez \& Simberloff 2003, 2004). A pesar de que para algunas especies los registros de campo resultaron discontinuos a lo largo del gradiente, asumimos su presencia en sitios intermedios (\$). Para nuestros propios registros, los números indican la cantidad de individuos capturados en cada sitio. La abundancia de T. niveibarbis en LT y VB está subestimada debido a que las capturas se restringieron a un mínimo. $\mathrm{CH}=$ registros de varios sitios en la vertiente chilena de los Andes a aproximadamente la misma latitud (Stuardo 1939, Angulo 1971, Bernardi 1973), PB = Puerto Blest (3.000 mm), LQ = Lago Queñi, PP = Paso Puyehue, LT = Lago Tromen, AP = Arroyo Pedregoso, VB = Viuda de Barriga, VT = Villa Traful, LH = Lago Huechulafquen, $\mathrm{C}=$ Caviahue, $\mathrm{LL}=$ La Lipela, CT $=$ Confluencia Traful. Se proporcionan los valores de precipitación media anual $(\mathrm{mm})$ de cada sitio. Por simplicidad los registros de estudios previos fueron asignados cuando fue posible a uno de nuestros propios sitios con precipitación equivalente

\begin{tabular}{|c|c|c|c|c|c|c|c|c|c|c|c|c|}
\hline Species & $\mathrm{CH}$ & $\mathrm{PB}$ & LQ & PP & $\mathrm{LT}$ & AP & VB & VT & $\mathrm{LH}$ & $\mathrm{C}$ & LL & CT \\
\hline $\begin{array}{l}\text { Mean annual } \\
\text { precipitation }(\mathrm{mm})\end{array}$ & & 3,000 & 2,550 & 2,000 & 1,750 & 1,700 & 1,450 & 1,250 & 1,050 & 1,000 & 750 & 700 \\
\hline T. philippii Rondani & $\dagger$ & $\dagger$ & 4 & $\S$ & 3 & $\S$ & 2 & & & & & \\
\hline T. nubipennis Rondani & $\dagger$ & & 4 & & & & & & & & & \\
\hline T. amoena Bigot & $\dagger$ & & & $2 \ddagger$ & $\ddagger$ & $\ddagger$ & $\dagger$ & $\S$ & $\dagger$ & & & \\
\hline T. jaffueli Stuardo Ortiz & $\dagger$ & & & $\ddagger$ & $\ddagger$ & $6 \ddagger$ & $\S$ & 1 & $\S$ & 4 & & \\
\hline T. porteri Stuardo Ortiz & $\dagger$ & & & & 4 & & & & & & & \\
\hline T. sp. 1 & & & & & 2 & & & & & & & \\
\hline T. niveibarbis (Bigot) & $\dagger$ & & & & 4 & $\S$ & 10 & & & & & \\
\hline T. andina (Philippi) & $\dagger$ & & & & & 1 & & & & & & \\
\hline T. sp. 2 & & & & & & & & & 1 & & & \\
\hline
\end{tabular}

\section{Flower-visitors overlap and floral characters}

Plants visited by tangle-veined flies were also visited by an average of 17.38 additional species (range: 2-65, Table 3) among which Diptera, Hymenoptera, Coleoptera, Lepidoptera and birds were present (Fig. 2). The diversity of the visitor assemblage of the plants visited by tangleveined flies varied markedly among species and sites (Fig. 2). For instance, whereas three animal species visited Cerastium arvense, Discaria chacaye received visits from 65 additional species. As an example of inter-site variation, Embothrium coccineum received 10 species of flower visitors at LT (four Hymenoptera, two Diptera, two Nemestrinidae and two birds, including one hummingbird species; Fig. 2) and 19 at LQ (eight Diptera, six Hymenoptera, two Coleoptera, one Lepidoptera, one Nemestrinidae and one hummingbird; Fig. 2). 


\section{TABLE 3}

Summary of records of interactions between Trichophthalma species and local flora in NW Patagonia, Argentina. Numbers on the intersections of rows and columns indicate the number of species of additional flower visitors that share the floral resources (columns) with the species of tangle-veined flies (rows). LQ = Lago Queñi, PP = Paso Puyehue, LT = Lago Tromen, AP = Arroyo Pedregoso, $\mathrm{VB}=$ Viuda de Barriga, VT = Villa Traful, $\mathrm{LH}=$ Lago Huechulafquen, $\mathrm{C}=$ Caviahue .

The lengths (and range) of the proboscides of Trichophthalma species is also indicated

Resumen de registros de interacciones entre especies de Trichophthalma y la flora local en el NO de Patagonia, Argentina. Los números en la intersección entre filas y columnas indican el número de especies de visitantes florales adicionales que comparten los recursos florales (columnas) con las especies de Nemestrínidos (filas). LQ = Lago Queñi, PP = Paso Puyehue, $\mathrm{LT}=$ Lago Tromen, $\mathrm{AP}=$ Arroyo Pedregoso, VB = Viuda de Barriga, VT = Villa Traful, $\mathrm{LH}=\mathrm{Lago}$ Huechulafquen, $\mathrm{C}=$ Caviahue. Se presenta también longitud (y el rango) de la probóscide de las especies de Trichophthalma

\begin{tabular}{|c|c|c|c|c|c|c|c|c|c|c|c|c|c|}
\hline \multirow{2}{*}{$\begin{array}{l}\text { Trichophthalma } \\
\text { species (number } \\
\text { of individuals) }\end{array}$} & \multirow{2}{*}{$\begin{array}{l}\text { Mean length } \\
\text { (range) of the } \\
\text { proboscides }(\mathrm{mm})\end{array}$} & \multirow[t]{2}{*}{ Site } & \multicolumn{11}{|c|}{ Host plant } \\
\hline & & & $\mathrm{Ab}$ & $\mathrm{A} 1$ & $\mathrm{Be}$ & $\mathrm{Bg}$ & $\mathrm{Ca}$ & $\mathrm{C}$ & $\mathrm{Dc}$ & $\mathrm{Ev}$ & $\mathrm{Ec}$ & Gp & $\mathrm{Hr}$ \\
\hline T. amoena (2) & $4.93(4.59-5.27)$ & $\mathrm{PP}$ & & 9 & & & & & & & & 12 & \\
\hline T. andina (1) & 6.36 & AP & & & & & & & & & & & 9 \\
\hline T.porteri (4) & $4.98(4.71-5.21)$ & $\mathrm{LT}$ & & & 7 & & & & 65 & & & & \\
\hline \multirow[t]{3}{*}{ T. jaffueli (9) } & $5.39(3.99-10.05)$ & $\mathrm{AP}$ & & & & & 2 & & & & & & 9 \\
\hline & & VT & & & & & & 5 & & & & & \\
\hline & & $\mathrm{C}$ & & & & & & & & 0 & & & \\
\hline T. niveibarbis (13) & $7.73(5.87-10.00)$ & $\mathrm{LT}$ & & & & & & & & & 9 & & \\
\hline T. nubipennis (4) & $7.15(6.86-7.34)$ & LQ & & & & & & & & 30 & & & \\
\hline \multirow[t]{2}{*}{ T.philippii (9) } & $8.89(7.74-11.00)$ & $\mathrm{LT}$ & & & & & & & & & 9 & & \\
\hline & & LQ & & & & & & & 46 & & 18 & & \\
\hline T. sp. 1 (2) & $3.72(3.44-4.00)$ & $\mathrm{LT}$ & & & 7 & 32 & & & & & & & \\
\hline T. sp. $2(1)$ & 5.95 & LH & 9 & & & & & & & & & & \\
\hline
\end{tabular}

\section{TABLE 4}

Shape and length of the flower tube of plant species visited by species of Trichophthalma in NW

Patagonia, Argentina. Characters are based on Correa (1969-1999) and our own data $(\dagger)$. Ab:

Adesmia boronioides; Al: Azara lanceolada; Be: Berberis empetrifolia; Bg: Buddleja globosa; C:

Carduus sp.; Ca: Cerastium arvense; Dc: Discaria chacaye; Ec: Embothrium coccineum; Ev: Escallonia virgata; Gp: Gaultheria phillyreaefolia; Hr: Hypochaeris radicata

Forma floral y longitud del tubo floral de las especies de plantas visitadas por especies de Trichophthalma en el NO de Patagonia, Argentina. La caracterización se basa en Correa (1969-1999) y en datos propios ( $\dagger$ ). Ab: Adesmia boronioides; Al: Azara lanceolada; Be: Berberis empetrifolia; Bg: Buddleja globosa; C: Carduus sp.; Ca: Cerastium arvense; Dc: Discaria chacaye; Ec: Embothrium coccineum; Ev: Escallonia virgata; Gp: Gaultheria phillyreaefolia; Hr: Hypochaeris radicata

\begin{tabular}{llll}
\hline Species & Family & Floral shape & Flower tube length (mm) \\
\hline Adesmia boronioides J. D. Hooker & Fabaceae & Papilionate & $7-10$ \\
Azara lanceolata J. D. Hooker & Flacourtiaceae & Brush & 0 \\
Berberis empetrifolia Lam. & Berberidaceae & Concave disc & 0 \\
Buddleja globosa Hope & Buddlejaceae & Bell-shaped & $3.5-6$ \\
Cerastium arvense L. & Caryophyllaceae & Concave disc & 0 \\
Carduus sp. & Asteraceae & Tubular & 12 \\
Discaria chacaye (G. Don.) Tortosa & Rhamnaceae & Tubular & 1 \\
Escallonia virgata (Ruiz et Pavón) Persoon & Escalloniaceae & Flat disc & 0 \\
Embothrium coccineum J.R. \& G. Forster & Proteaceae & Tubular & $14 \dagger$ \\
Gaultheria phillyreaefolia (Pers.) Sleumer & Ericaceae & Urceolate & 4 \\
Hypochaeris radicata L. & Asteraceae & Tubular & 10
\end{tabular}




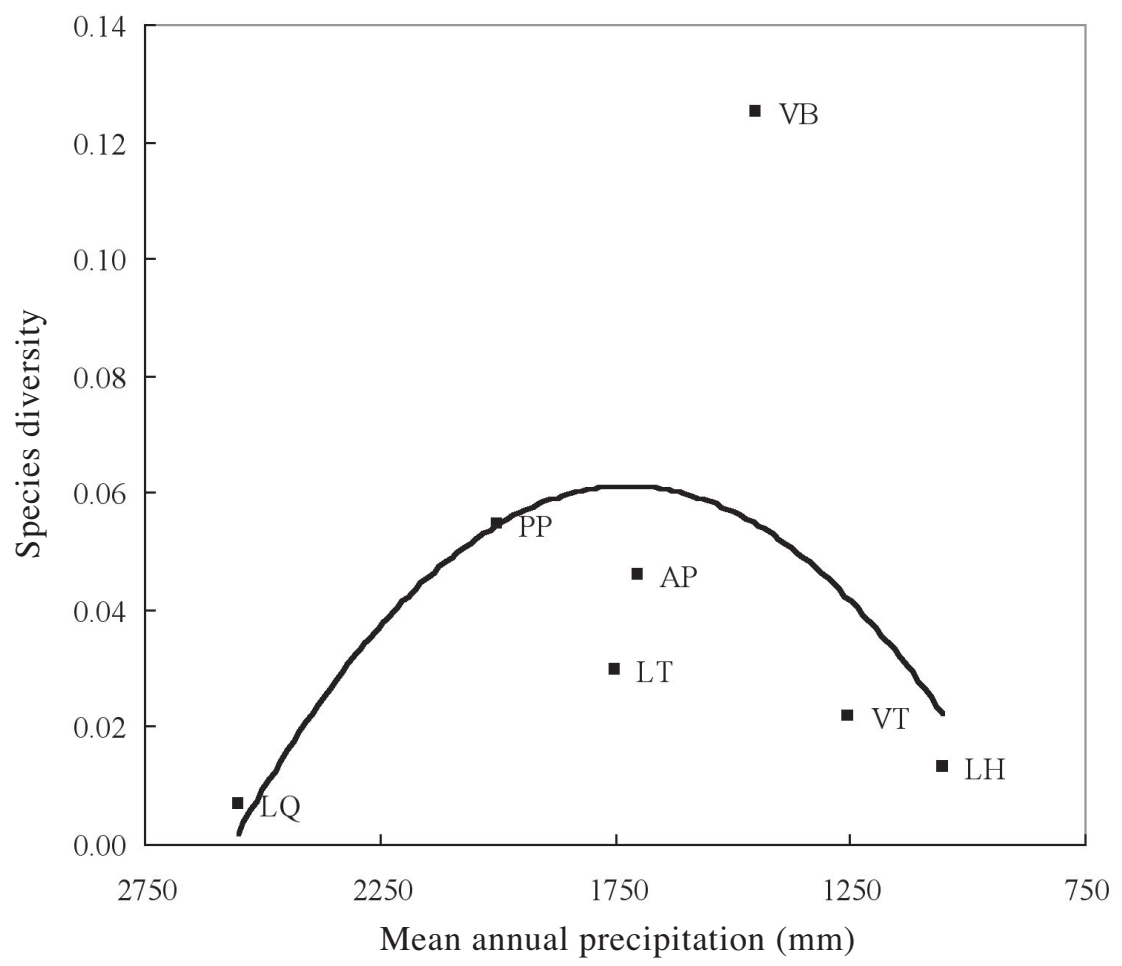

Fig. 1: Diversity $(\gamma)$ of Trichophthalma species along a rainfall gradient in north west Patagonia, Argentina. See Table 2 and its references for further details on source of the data. From left to right, sites are ordered by decreasing mean annual precipitation (Pre) to better reflect their actual geographic position (Pre decreases to the east). In addition to our own data, we only used registers of which sampling effort employed was provided (Vázquez \& Simberloff 2002). Field data on species richness was standardized for sampling effort at each site. A second-degree polynomial function was fitted to the transformed data $\left(\gamma=9 \times 10^{-8} \mathrm{Pre}^{2}+0.0003\right.$ Pre $\left.-0.1955, \mathrm{R}^{2}=0.314\right)$.

Diversidad $(\gamma)$ de especies Trichophthalma a lo largo de un gradiente de humedad en el noroeste de la Patagonia, Argentina. Ver la Tabla 2 y sus referencias para más detalles sobre la fuente de los datos. De izquierda a derecha los sitios están ordenados por precipitación media anual (Pre) decreciente para reflejar mejor su posición geográfica real (Pre decrece hacia el este). Además de los datos propios, solo se utilizaron registros que proporcionaran el esfuerzo de muestreo empleado (Vázquez \& Simberloff 2002). La riqueza registrada a campo fue estandarizada por el esfuerzo de muestreo en cada sitio (Tabla 1). Se ajustó a los datos transformados una función polinomial de segundo grado $\left(\gamma=9 \times 10^{-8} \mathrm{Pre}^{2}+\right.$ 0.0003 Pre $\left.-0.1955, \mathrm{R}^{2}=0.314\right)$.

\section{DISCUSSION}

Our study adds a considerable amount of information on the ecology of Nemestrinidae at the temperate forests of southern South America on the Argentinean side of the Andes. Together with new records for Argentina of already described species and the finding of two undescribed taxa, we reported several pollination interactions with the local flora.

There are a few previous records of tangleveined flies visiting flowers of the local Patagonian flora (Edwards 1930, Stuardo 1939, Riveros et al. 1991, Vázquez \& Simberloff 2003, 2004, Smith-Ramírez et al. 2005). However, these could be only partially incorporated into our analysis mainly because of lack of detail on sampling effort employed and on the identity of the plant and animal species involved (Vázquez \& Simberloff 2002, 2003, 2004 constitutes an exception on this regard) or because they were made too far from our study sites (e.g., SmithRamírez et al. 2005). Considering community level data available for six of our sites (Devoto et al. 2005, no data available for VB and C), Nemestrinidae visited on average $10.9 \%$ (range $=3.5-17.4)$ of all the plant species that received visits from any pollinator taxa during fieldwork. Comparable values reported for the region of $12.9 \%$ (of 31 plant species at Puyehue, Chile, Riveros et al. 1991), $3.8 \%$ (of 26 plant species at Chiloé, Chile, Smith-Ramírez et al. 2005) and 
$14.2 \%$ (average from eight communities of 15 plants each at Nahuel Huapi, Argentina, Vázquez \& Simberloff 2002), suggest Nemestrinidae are possible pollinators of a substantial portion of the anthophilous plant species of the temperate forests of southern South America, although further research on their effectiveness as pollinators is required to confirm this.

This study proves valuable in light of the present scarcity of information on the ecology of the Patagonian species of Nemestrinidae. Throughout eight sites, we recorded nine species belonging to the genus Trichophthalma visiting flowers of the local flora. Of the nine species, three were unrecorded for Argentina (T. andina, $T$. porteri and $T$. niveibarbis) and two other (represented by three captured individuals that did not fit into the available keys for the genus) are here considered as yet undescribed taxa. Trichophthalma nubipennis had been reported for Argentina but is here first recorded as visitor to the local flora (Table 3 ). Overall, we found in the field 7 of the 21 species of Trichophthalma described for southern South America (Argentina, Chile and Uruguay; Bernardi 1973, 1975), besides the two undescribed species mentioned above.

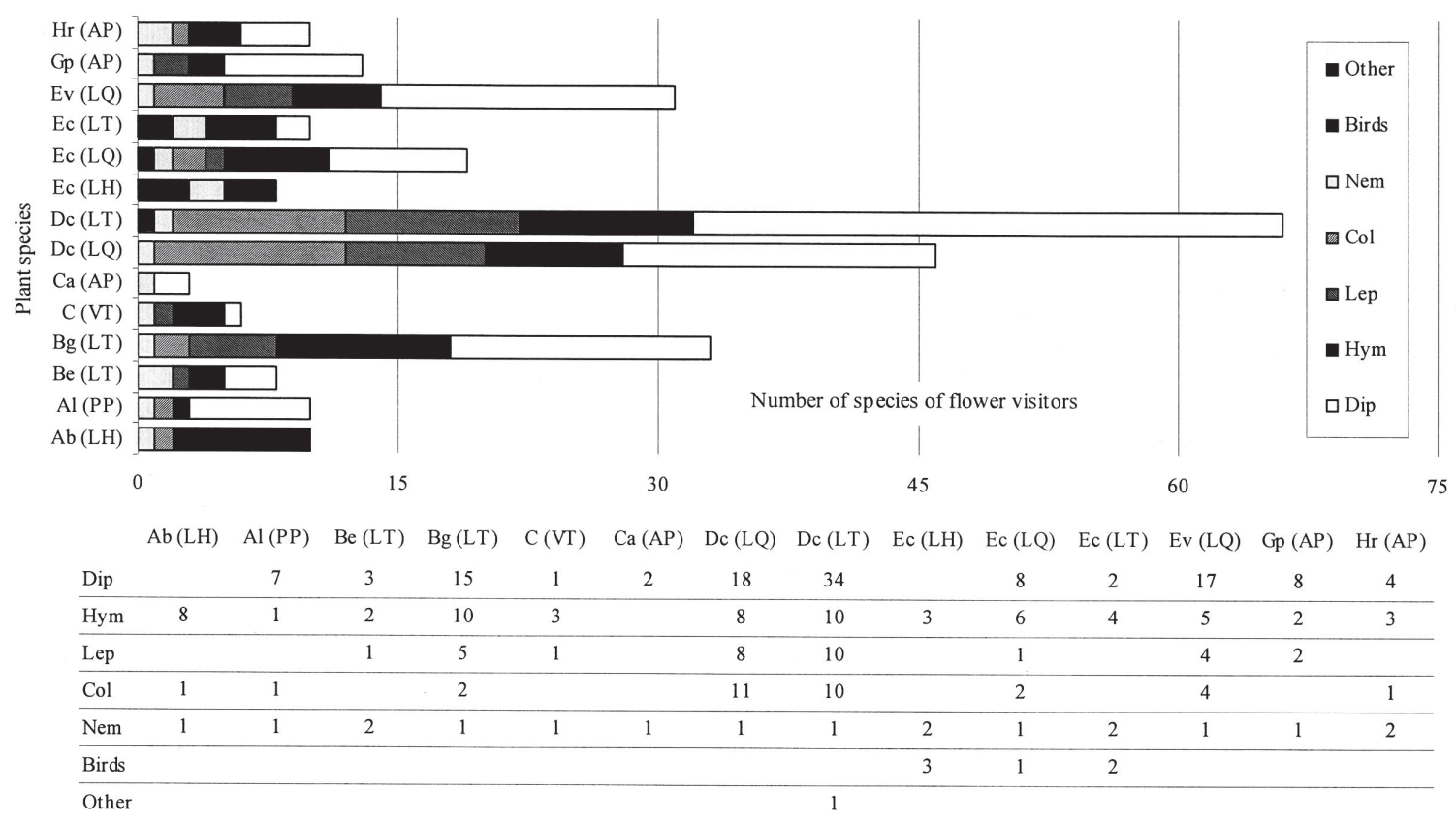

Fig. 2: Composition of the complete flower-visitor assemblage of plants visited by tangle-veined flies in NW Patagonia, Argentina. The numbers in the table indicate the total amount of species of each order recorded and they correspond to the lengths of the bars above. Plant species: $\mathrm{Hr}=$ Hypochaeris radicata, $\mathrm{Gp}=$ Gaultheria phillyreaefolia, $\mathrm{Ec}=$ Embothrium coccineum, $\mathrm{Ev}=$ Escallonia virgata, $\mathrm{Dc}=$ Discaria chacaye, $\mathrm{Be}=$ Berberis empetrifolia, $\mathrm{Bg}=$ Buddleja globosa, $\mathrm{Ca}=$ Cerastium arvense, $\mathrm{C}=$ Carduus sp., $\mathrm{Al}=$ Azara lanceolada, $\mathrm{Ab}=$ Adesmia boronioides. The site where interactions were recorded is indicated between brackets beside the plant species. AP = Arroyo Pedregoso, LQ = Lago Queñi, LT = Lago Tromen, LH = Lago Huechulafquen, VT = Villa Traful, PP = Paso Puyehue.

Composición del elenco completo de visitantes florales de las plantas visitadas por nemestrínidos en el noroeste de la Patagonia, Argentina. Los números en la tabla inferior indican la cantidad total de especies de cada orden registradas y se corresponden con la longitud de las barras superiores. Especies vegetales: Hr = Hypochaeris radicata, Gp = Gaultheria phillyreaefolia, $\mathrm{Ec}=$ Embothrium coccineum, $\mathrm{Ev}=$ Escallonia virgata, $\mathrm{Dc}=$ Discaria chacaye, $\mathrm{Be}=$ Berberis empetrifolia, $\mathrm{Bg}=$ Buddleja globosa, $\mathrm{Ca}=$ Cerastium arvense, $\mathrm{C}=$ Carduus $\mathrm{sp} ., \mathrm{Al}=$ Azara lanceolada, $\mathrm{Ab}=$ Adesmia boronioides. Los sitios en que las interacciones fueron registradas se indican entre paréntesis a continuación del nombre de las plantas. AP = Arroyo Pedregoso, LQ = Lago Queñi, LT = Lago Tromen, LH = Lago Huechulafquen, VT = Villa Traful, PP = Paso Puyehue. 


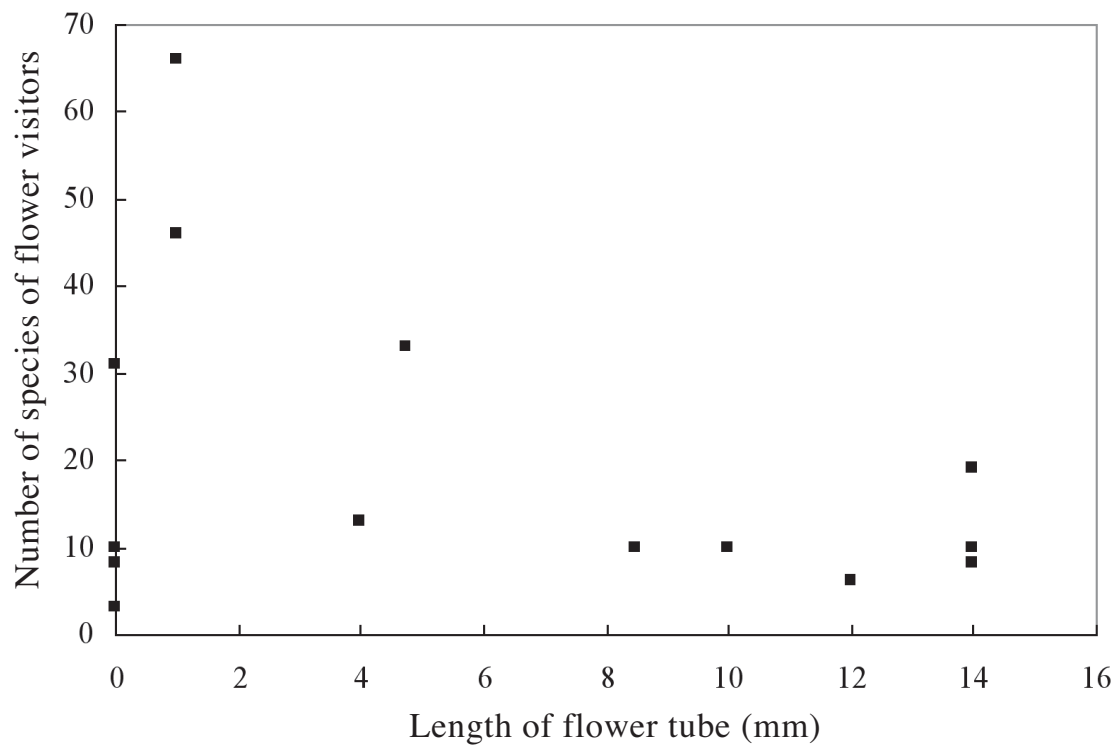

Fig. 3: Relationship between the length of the flower tube of plant species visited by tangle-veined flies (data from Table 4) and their total number of species of flower visitors in north west Patagonia, Argentina.

Relación entre la longitud del tubo floral de las especies de plantas visitadas por nemestrínidos (datos de la Tabla 4) y su número total de especies de visitantes florales en el noroeste de la Patagonia, Argentina.

Most notably, it is reported for the first time in South America (second time worldwide, Manning 2004) a pollination interaction between tangle-veined flies and a Proteaceaous plant ( $T$. niveibarbis and $T$. philippii pollinating E. coccineum, Table 3 ). This is interesting in the light of the common Gondwanian origin and present Austral distribution of both families, which suggests an ancient origin for this mutualism (Montaldo et al. 1999) ${ }^{1}$. To our knowledge, this is also the first report of pollination interactions between Nemestrinidae and two other plant genera with Gondwanian distribution (Discaria and Gaultheria, Table 3).

The pattern of species richness of Nemestrinidae along the precipitation gradient roughly followed a bell-shaped distribution, with highest abundances achieved at intermediate points of the gradient $(\sim 1,700$ $\mathrm{mm}$ ) and decreasing towards both its driest and wettest ends (Fig. 1). The complete absence of Nemestrinidae at the driest sites of the gradient

\footnotetext{
${ }^{1}$ MONTALDO NH, GG ROITMAN, M DEVOTO \& D MEDAN (1999) Biología reproductiva de Embothrium coccineum (Proteaceae) en la Provincia de Neuquén. XIX Reunión Argentina de Ecología, Tucumán, Libro resúmenes: 106 .
}

is in accordance with the regional (and global) pattern followed in general by all Diptera, whose diversity shows a marked decrease in dryer environments (Devoto et al. 2005). However, it should be considered that Trichophthalma species were absent from the driest sites because the plant species they feed on at other sites were not present there. While this may be true for four species (T. amoena, $T$. porteri, $T$. nubipennis and $T$. sp. 2) the absence of the remaining five species cannot be attributed to this cause; i.e. in the drier sites there are plant species which Trichophthalma spp. visited somewhere else in the region (e.g., $E$. coccineum for $T$. philippii and $T$. niveibarbis). Moreover, at the drier places two of the absent Trichophthalma species would have alternative plants to feed on which are congeneric with their original host plants (e.g., Discaria articulata for T. porteri).

Among Trichophthalma species of the eastern slope of the Andes, we found a very weak correspondence between plant distribution and their Nemestrinidae visitors. Our data (Table 2) shows that the longitudinal distribution of a given species of tangle-veined flies can sometimes encompass a marked 
change in rainfall and in the accompanying vegetation (e.g., rainfall measures on the western range limits of $T$. philippii, $T$. jaffueli and $T$. amoena double those of the eastern limits).

\section{Nemestrinidae of southern Africa}

In southern Africa pollination by Nemestrinidae is well-documented (Marloth 1908, Vogel 1954, Johnson \& Steiner 1995). Ten species of Nemestrinidae belonging to the genera Moegistorhynchus, Prosoeca and Stenobasipteron have been reported to participate in highly specialized pollination interactions with an exclusive guild of species with long floral tubes (Manning \& Goldblatt 1996, 1997, Goldblatt \& Manning 2000, Manning 2004).

In comparison, the Patagonian Nemestrinidae result much less specialized since they share their floral resources with a diverse and little specialized fauna (Fig. 2 and Table 3). A cause for this can be envisioned in the morphology of the flowers on which tangle-veined flies feed in Patagonia: their open or short-tubed flowers do not hinder the access of other species to the floral resources (Table 4), unlike the long-tubed African guild (Goldblatt \& Manning 2000). However, in Patagonia the species with longer flower tubes seem to have a lower maximum number of flower visitors (i.e. they are more specialized) than the shorter-tubed species, although this trend is not significant $(P=0.06$, $\mathrm{F}_{1,6}=4.90, \mathrm{R}^{2}=0.44$; Fig. 3 ). On the other side, there is a notorious contrast between the morphology of African Nemestrinidae, which have proboscides at least $15 \mathrm{~mm}$ long (as described by Goldblatt \& Manning 2000), and the Patagonian species of Nemestrinidae that we captured whose proboscides range between 3.7 and $8.8 \mathrm{~mm}$ in length (Table 3 ).

\section{Nemestrinidae of eastern Australia}

Nemestrinidae are also remarkably abundant in Australia where Trichophthalma is the dominant genus (45 species, Bernardi 1975). At the montane rainforests of eastern Australia there are at least 19 species belonging to this genus (Williams 2002). These sites constitute a relict environment closely resembling the temperate forests of southern South America. Unfortunately, there seems to be a lack of studies on the ecology of tangle-veined flies, including Trichophthalma, in Australia. Further research there is likely to allow for interesting comparisons with the "South American connection" of the family.

We hope that this paper will encourage further research on Nemestrinidae and their associated flowers. For example, the coexistence of this ancient group with more 'modern' hummingbirds in the visitor assemblage of the 'ornithophilous' (yet also Gondwanian as Nemestrinidae) E. coccineum is an interesting scenario that may allow for the testing of hypothesis by evolutionary biologists (Thompson 1998, Gomulkiewicz et al. 2003). Overall, much remains to be understood about the distribution, floral associations and general ecology of the species of Nemestrinidae of southern South America.

\section{ACKNOWLEDGEMENTS}

We thank A. Basilio, M. Chamer, G. Gleiser, V. Medan, N. H. Montaldo, G. G. Roitman, L. Rossi and J. P. Torretta for their help in the field and laboratory. An earlier version of this paper benefited from comments by two anonymous reviewers. This work was financed by grants from UBACyT and Consejo Nacional de Investigaciones Científicas y Técnicas (CONICET). A graduate research scholarship granted by the University of Buenos Aires to M. D. is also gratefully acknowledged. Diego Medan is associated to the CONICET.

\section{LITERATURA CITED}

AIZEN MA, DP VÁZQUEZ \& C SMITH-RAMÍREZ (2002) Historia natural y conservación de los mutualismos planta-animal del bosque templado de Sudamérica austral. Revista Chilena de Historia Natural 75: 79-97.

ANGULO AO (1971) Los nemestrínidos de Chile (Diptera: Nemestrinidae). Gayana Zoologia (Chile) 19: 1-172.

ARROYO MTK, L CAVIERES, A PEÑALOZA, M RIVEROS \& A FAGGI (1996) Phytogeographic relationships and species richness patterns in the temperate rain forest flora of South America. En: Armesto J, C Villagrán \& MTK Arroyo (eds) Ecología de los bosques nativos de Chile: 71-100. Editorial Universitaria, Santiago de Chile, Chile.

ARROYO MTK, R PRIMACK \& J ARMESTO (1982) Community studies in pollination ecology in the high temperate Andes of central Chile. I. 
Pollination mechanisms and altitudinal variation. American Journal of Botany 69: 82-97.

AUSTIN AT \& OE SALA (2002) Carbon and nitrogen dynamics across a natural gradient of precipitation in Patagonia, Argentina. Journal of Vegetation Science 13: 351-360.

BERNARDI N (1973) The genera of the family Nemestrinidae (Diptera: Brachycera). Arquivos de Zoología (Brazil) 24: 211-318

BERNARDI N (1975) Uma nova Trichophthalma da Argentina (Diptera, Nemestrinidae). Revista Brasileira de Entomologia 19: 123-125.

BERNARDI N (1977) The tribe of Hyrmophlaebini (Diptera Nemestrinidae Hirmoneurinae) with 13 new species from South America. Papeis Avulsos de Zoologia (Brazil) 30: 239-259.

COLE FR (1969) The flies of western North America. University of California Press, Berkeley, California, USA. 693 pp.

CORREA NM (1969-1999) Flora patagónica. Instituto Nacional de Tecnología Agropecuaria (INTA), Buenos Aires, Argentina. 3,118 pp.

DEVOTO M, D MEDAN \& NH MONTALDO (2005) Patterns of interaction between plants and pollinators along an environmental gradient. Oikos 109: 461-472.

DONOSO ZEGERS C (1993) Bosques templados de Chile y Argentina. Editorial Universitaria, Santiago, Chile. 485 pp.

EDWARDS FW (1930) Nemestrinidae. Diptera of Patagonia and south Chile. Volume 2: 179-187. British Museum of Natural History, London, United Kingdom.

GOLDBLATT P \& JC MANNING (2000) The longproboscid fly pollination system in southern Africa. Annals of the Missouri Botanical Garden 87: 146170.

GOMULKIEWICZ R, SL NUISMER \& JN THOMPSON (2003) Coevolution in variable mutualisms. American Naturalist 162: S80-S93.

HERRERA CM (2005) Plant generalization on pollinators: species property or local phenomenon? American Journal of Botany 92: 13-20

JOHNSON SD \& KE STEINER (1995) Long-proboscid fly pollination of two orchids in the Cape Drakensberg mountains, South Africa. Plant Systematics and Evolution 195: 169-175.

JOHNSON SD \& KE STEINER (2000) Generalization versus specialization in plant pollination systems. Trends in Ecology and Evolution 15: 140-143.

MANNING J (2004) Needles and pins. Horseflies and other long-proboscid flies spotted pollinating pincushions (from the Protea family) for the very first time. Veld \& Flora 90: 10-12.

MANNING JC \& P GOLDBLATT (1996) The Prosoeca peringueyi (Diptera: Nemestrinidae) pollination guild in southern Africa: long-tongued flies and their tubular flowers. Annals of the Missouri Botanical Garden 83: 67-86.

MANNING JC \& P GOLDBLATT (1997) The Moegistorhynchus longirostris (Diptera: Nemestrinidae) pollination guild: long-tubed flowers and a specialized long-proboscid fly pollination system in southern Africa. Plant Systematics and Evolution 206: 51-69.

MARLOTH R (1908) Some observations on entomophilous flowers. South African Association for the Advancement of Science 4: 110-113

MOSTOVSKI MB \& X MARTÍNEZ DELCLOS (2000) New Nemestrinoidea (Diptera: Brachycera) from the Upper Jurassic-Lower Cretaceous of Eurasia, taxonomy and palaeobiology. Entomological Problems 31: 137-148

MOVIA CP, GH OWER \& CE PÉREZ (1982) Estudio de la vegetación natural de la Provincia del Neuquén. Ministerio de Economía y Hacienda, Subsecretaría de Estado de Recursos Naturales, Argentina. 59 pp.

PARUELO JM, AM BELTRÁN, E JOBBÁGY, OE SALA \& RA GOLLUSCIO (1998a) The climate of Patagonia: general patterns and controls on biotic processes. Ecología Austral (Argentina) 8: 85-101.

PARUELO JM, EG JOBBAGY \& OE SALA (1998b) Biozones of Patagonia (Argentina). Ecología Austral (Argentina) 8: 145-153.

PEÑA GLE (1996) Introducción al estudio de los insectos de Chile. Editorial Universitaria, Santiago, Chile. $253 \mathrm{pp}$.

POTTS SG, B VULLIAMY, A DAFNI, G NE'EMAN, C O'TOOLE, S ROBERTS \& P WILLMER (2003) Response of plant-pollinator communities to fire: changes in diversity, abundance and floral reward structure. Oikos 101: 103-112.

RAVEN PH \& DI AXELROD (1974) Angiosperm biogeography and past continental movements. Annals of the Missouri Botanical Garden 61: 539-673.

RAVEN PH \& DI AXELROD (1975) History of the flora and fauna of Latin America. American Science 63: 420-429.

RIVEROS MG, AM HUMAÑA \& D LANFRANCO (1991) Actividad de los polinizadores en el Parque Nacional Puyehue, X Región, Chile. Medio Ambiente (Chile) 11: 5-12.

RIVEROS MG \& C SMITH-RAMÍREZ (1996) Patrones de floración y fructificación en bosques del sur de Chile. In: Armesto J, C Villagrán \& MTK Arroyo (eds) Ecología de los bosques nativos de Chile: 71100. Editorial Universitaria, Santiago, Chile.

SMITH-RAMÍREZ C \& JJ ARMESTO (1994) Flowering and fruiting patterns in the temperate rainforest of Chiloé, Chile - ecologies and climatic constraints. Journal of Ecology 82: 353-365.

SMITH-RAMÍREZ C, P MARTÍNEZ, M NÚÑEZ, C GONZÁLEZ \& JJ ARMESTO (2005) Diversity, flower visitation frequency and generalism of pollinators in temperate rain forests of Chiloé Island, Chile. Botanical Journal of the Linnean Society 148: 399-416.

SORIANO A (1983) Deserts and Semi-deserts of Patagonia. In: West NE (ed) Ecosystems of the world: temperate deserts and semi-deserts: 423-460. Elsevier, Amsterdam, The Netherlands.

SORIANO A, HA ALIPPE, OE SALA, TM SCHILCHTER, CP MOVIA, RJC LEÓN, R TRABUCO \& VA DEREGIBUS (1976) Ecología del pastizal de coirón amargo (Stipa speciosa) del sudoeste de Chubut. Academia Nacional de Ciencias Agrícolas y Veterinarias (Argentina) 30: $1-13$.

STUARDO C (1939) Los Nemestrinidae (Diptera) de la República Argentina. Physis (Argentina) 17: 77-94.

THOMPSON JN (1998) The population biology of coevolution. Researches on Population Ecology 40: 159-166.

VÁZQUEZ DP \& D SIMBERLOFF (2002) Ecological specialization and susceptibility to disturbance: conjectures and refutations. American Naturalist 159: 606-623.

VÁZQUEZ DP \& D SIMBERLOFF (2003) Changes in interaction biodiversity induced by an introduced ungulate. Ecology Letters 6: 1077-1083. 
VÁZQUEZ DP \& D SIMBERLOFF (2004) Indirect effects of introduced ungulates on pollination and plant reproduction. Ecological Monographs 74: 281-308.

VOGEL S (1954) Blütenbiologische Typen als Elemente der Sippengliederung, dargestellt anhand der Flora Südafrikas. Botanische Studien 1: 1-338.

WILLEMSTEIN SC (1987) An evolutionary basis for pollination ecology. Leiden University Press, Leiden, The Netherlands. $425 \mathrm{pp}$.

Editor Asociado: Audrey Grez

Recibido el 7 de abril de 2005; aceptado el 8 de junio de 2005
WILLIAMS G (2002) A taxonomic and biogeographic review of the invertebrates of the central eastern rainforest reserves of Australia (CERRA) World Heritage Area, and adjacent regions. Technical Reports of the Australian Museum 16: 1-208.

WILLIAMS NM, RL MINCKLEY \& FA SILVERA (2001) Variation in native bee faunas and its implications for detecting community change. Conservation Ecology 5: 57-89. 